\title{
ANALISIS DESKRIPTIF TERHADAP INOVASI LAYANAN APLIKASI SAMBARA (Samsat Mobile Jawa Barat)
}

\author{
Ari Ramdani \\ Prodi Ilmu Administrasi Negara \\ STIA YPPT Priatim Tasikmalaya \\ dosenmuda1983@gmail.com
}

\begin{abstract}
Abstrak
Penelitian ini berbicara terkait dengan inovasi layanan publik berupa aplikasi SAMBARA (Samsat Mobile Jawa Barat). Penelitian ini berupaya untuk menggali sejauhmana kebermamfaatan inovasi layanan tersebut dan berupaya untuk mendapatkan jawaban mengenai penyebab Badan Pendapatan Daerah (BAPENDA) Jawa Barat dapat melakukan inovasi layanan aplikasi SAMBARA ini. Penelitian ini dilakukan dengan menggunakan metode penelitian kualitatif dengan analisis deskriptif. Beberapa temuan dari penelitian ini diketahui bahwa inovasi layanan ini banyak membantu masyarakat untuk membayar pajak kendaraan bermotornya kapan saja dan dimana saja dan pada akhirnya dapat meningkatkan pendapatan pemerintah daerah provinsi Jawa Barat. Temuan lainnya adalah faktor pendukung, diantaranya adalah political will dari para pejabat, kemudian pula tidak lepas dari faktor dari pihak swasta baik itu perbankan ataupun perusahaan-perusahaan atau toko online semacam bukalapak, indomaret yang mengakomodir pembayaran pajak tahunan kendaraan bermotor, yang memudahkan masyarakat dalam mendapatkan layanan ini.
\end{abstract}

Kata Kunci: Inovasi, Layanan, Aplikasi, Sambara

\section{PENDAHULUAN}

Pelayanan publik merupakan salah satu upaya pemerintah dalam meningkatkan tingkat kesejahteraan masyarakat. dengan pelayanan publik itulah kebutuhan masyarakat di berbagai bidang dapat terpenuhi. Karena inilah subtansi tujuan dari pelayanan publik itu sendiri. Semakin bagus pelayanan publik yang diberikan pemerintah kepada masyarakat, maka semakin meningkat pula tingkat kesejahteraan masyarakat. Namun kenyataannya belumlah seperti itu. Masih terdapat kendala dalam implementasi pelayanan publik, mulai dari kendala birokrasi sampai dengan kendala prosedural yang dianggap terlalu rumit dalam pemberian pelayanan publik. Hal inilah yag menyebabkan menjadikan pelayanan publik yang diberikan oleh pemerintah masih kalah jauh dengan pelayanan publik yang diberikan oleh sektor swasta. Seehingga wajar saja kalau akhir-akhir ini digencarkan upaya pemerintah untuk mengejar ketertinggalan tersebut melalui terobosan-terobosan baru dengan apa yang dikenal sebagai inovasi pelayanan publik. 
Inovasi pelayanan publik sudah mulai banyak dilakukan oleh pemerintah baik pemerintah pusat maupun pemerintah daerah baik dalam skala makro sampai dengan skala mikro, mulai dari dibuatnya mall pelayanan publik seperti di Banyuwangi sampai dengan hal mikro berupa digitalisasi pelayanan yang tidak perlu membutuhkan pelayanan secara face to face. Inovasi pelayanan publik mendapatkan peluang untuk dapat diimplementasikan di masing-masing daerah seiring dengan adanya otonomi daaerah, tinggal peran kepemimpinan yang kuat yang diperlukan dalam menerapkan inovasi pelayanan publik. Inovasi pelayanan publik pun sudah banyak dilakukan oleh berbagai instansi pemerintah pusat, maupun daerah provinsi, kabupaten maupun kota. Tak terkecuali oleh Badan Pendapatan Daerah Propinsi Jawa Barat (BAPENDA Jabar).

Setelah sukses dengan Samsat Keliling yang diimplementasikan di berbagai daerah di wilayah Jawa Barat termasuk Kota Tasikmalaya dengan hasil yang baik dan memunculkan kepuasan dari masyarakat akan layanan tersebut (Ramdani, 2018), kini dalam upaya mempermudah dan meningkatkan mutu layanan tersebut BAPENDA Propinsi Jawa Barat mengeluarkan sebuah inovasi pelayanan baru yang dinamakan sebagai inovasi layanan aplikasi SAMBARA (Samsat Mobile Jawa Barat).

Tentunya inovasi layanan berupa aplikasi SAMBARA ini diharapkan dapat memberikan kemudahan dan kesederhanaan prosedur yang diperoleh oleh masyarakat dalam mendapatkan layanan berupa mengecek kendaraan bermotor, bayar pajak kendaraan bermotor, mengetahui jadwal samsat keliling dan lokasi samsat keliling. Namun apakah inovasi layanan aplikasi SAMBARA ini betul-betul bermamfaat dan memberikan pelayanan yang memuaskan bagi masyarakat Jawa Barat atau malah sebaliknya.

Dari uraian tersebut diatas, penulis tertarik untuk melakukan penelitian lanjutan dengan judul "Analisis Deskriptif Terhadap Inovasi Layanan Aplikasi SAMBARA". Penelitian ini ingin mencoba mengetahui beberapa hal yang penulis tuangkan dalam pertanyaan penelitian, yaitu 1). Sejauhmana kebermamfaatan dari inovasi layanan aplikasi SAMBARA ini? 2). Faktor apa yang menyebabkan BAPENDA dapat melakukan inovasi layanan aplikasi SAMBARA ini?

\section{A. Inovasi}

Inovasi Dalam (PerMenPan No 30 Tahun 2014 Tentang Pedoman Inovasi Pelayanan Publik), bahwa apa yang dinamakan sebagai inovasi adalah proses kreatif penciptaan pengetahuan dalam melakukan penemuan baru yang berbeda dan atau modifikasi dari yang sudah ada. Inovasi merupakan sebuah ide, praktek atau objek yang dianggap baru oleh individu satu unit dan diadopsi oleh unit lainnya. Everett M Rogers dalam (Suwarno, 2014) 
Inovasi adalah kegiatan yang meliputi seluruh proses menciptakan dan menawarkan jasa atau barang baik yang sifatnya baru, labih baik atau lebih murah dibandingkan dengan yang tersedia sebelumnnya. Bussiness 1000 dalam (Suwarno, 2014). Sedangkan menurut (Widodo, 2017), inovasi adalah penyederhanaan dan atau pengintegrasian tata laksana (business process). Sebuah Inovasi dapat berupa produk atau jasa yang baru, teknologi proses produksi yang baru, system struktur dan administrasi baru ata rencana baru bagi anggota Fariborz dalam (Suwarno, 2014) Inovasi itu tidak perlu besar-besar, melainkan kecil-kecil atau tidak muluk-muluk, tetapi memberikan dan menjadi sebuah solusi dalam pelayanan khususnya. Hal ini senada dengan apa yang disampaikan oleh (Widodo, 2017), bahwa inovasi itu memiliki karakteristik yaitu: 1). Ada tidaknya dampak positif atau kemamfaatan dari suatu inisiatif perubahan. 2). Mampu member solusi terhadap masalah, 3). Inovasi juga haruslah berkesinambungan. Tiga karakteritik inilah yang harus melekat dalam Inovasi Pelayanan Publik sebagaimana yang akan dijelaskan di bawah ini.

\section{B. Inovasi Pelayanan Publik}

Inovasi Pelayanan Publik Dalam (PerMenPan No 30 Tahun 2014 Tentang Pedoman Inovasi Pelayanan Publik), "Inovasi pelayanan publik adalah terobosan jenis pelayanan baik yang merupakan gagasan/ide kreatif orisinal dan atau adaptasi/modifikasi yang memberikan mamfaat bagi masyarakat, baik secara langsung maupun tidak langsung. Dengan kata lain, inovasi pelayanan publik sendiri tidak mengharuskan penemuan baru, tetapi dapat merupakan suatu pendekatan baru yang bersifat kontekstual dalam arti inovasi tidak terbatas dari tidak ada kemudian muncul gagasan dan praktik inovasi, tetapi dapat berupa inovasi hasil dari perluasan maupun peningkatan dan kualitas pada inovasi yang ada." Hal ini senada dengan apa yang disampaikan oleh (Widodo, 2017), bahwa inovasi itu memiliki karakteristik yaitu: 1). Ada tidaknya dampak positif atau kemamfaatan dari suatu inisiatif perubahan. 2). Mampu memberi solusi terhadap masalah, 3). Inovasi juga haruslah berkesinambungan.

\section{Samsat Mobile Jawa Barat (SAMBARA)}

Sambara ialah inovasi berbasis elektronik yang dibuat BAPENDA Jawa Barat yang fungsinya untuk melakukan pengecekan Pajak Kendaraan Bermotor di Wilayah Jawa Barat. Aplikasi tersebut dapat menampilkan informasi pajak kendaraan bermotor baik roda dua maupun roda empat di Jabar secara online (BAPENDA, 2019). Adapun fungsi SAMBARA lebih detailnya adalah sebagai berikut:

\section{Fungsi Inovasi Layanan Aplikasi SAMBARA}

Aplikasi SAMBARA ini memiliki fungsi sebagai berikut yaitu: 
1. Mengecek pajak kendaraan bermotor dan bayar pajak. Masyarakat Jawa barat dapat melakukan pengecekan pajak kendaraan secara online menggunakan aplikasi SAMBARA caranya sangat mudah yaitu dengan mengunduh melalui playstore setelah itu buka aplikasi SAMBARA dan pilih menu info PKB dan masukan plat nomor kendaraan anda lalu akan muncul informasi kendaraan dan pajak yang harus dibayar. Pada pojok kanan atas terdapat ikon lalu tekan setelah itu pilih tanda pada pojok bawah, dan anda dapat memilih pembayaran melalui SMS Banking atau Internet Banking.

2. Mengetahui jadwal samsat keliling dan samsat gendong. Selain dapat melakukan pengecekan kendaraan dalam aplikasi SAMBARA dapat juga mengetahui informasi tentang jadwal SAMLING (Samsat Keliling) dan SAMDONG (Samsat Gendong) di seluruh Daerah Jawa Barat

3. Mengetahui lokasi pelayanan samsat (BAPENDA, 2019)

\section{Kerangka Pemikiran}

\begin{tabular}{|l|l|l|}
\hline $\begin{array}{l}\text { Latar Belakang } \\
\text { Penelitian: } \\
\text { - } \\
\text { Digitalis } \\
\text { asi } \\
\text { Layanan } \\
\text { upaya } \\
\text { memper } \\
\text { mudah } \\
\text { dan } \\
\text { meningk } \\
\text { atkan } \\
\text { mutu } \\
\text { layanan }\end{array}$ & $\begin{array}{l}\text { Analisis } \\
\text { Deskriptif } \\
\text { kebermamfaatan } \\
\text { dari inovasi } \\
\text { layanan aplikasi } \\
\text { Terhadap } \\
\text { Inovasi } \\
\text { Layanan } \\
\text { Aplikasi } \\
\text { yang Faktor apa } \\
\text { menyebabkan } \\
\text { SAMBARA } \\
\text { BAPENDA dapat } \\
\text { melakukan } \\
\text { inovasi layanan } \\
\text { aplikasi } \\
\text { SAMBARA ini? }\end{array}$ \\
\end{tabular}

Dalam penelitian ini menggunakan pendekatan kualitatif dengan metode penelitian deskriptif yang menurut (Sugiyono, 2006) bahwa,

“dilakukan untuk mengetahui nilai variabel mandiri, baik satu variabel atau lebih (independen) tanpa membuat perbandingan atau menghubungkan antara variabel satu dengan variabel yang lain".

Adapun Informan penelitian ini adalah pihak-pihak yang berkaitan dengan inovasi layanan SAMBARA. Informan Penelitian hanya mengambil scoupe wilayah Kota Tasikmalaya saja. Teknik pengambilan informan berdasarkan teknik snow ball, dimana 
kemungkinan informan bisa bertambah atau berubah sampai mendapatkan informan key yang mampu memberikan informasi yang sesuai dengan apa yang penulis harapkan.

Sedangkan Teknik pengumpulan data yang dipergunakan dalam penelitian ini adalah: Observasi terkait layanan SAMBARA, Wawancara, Studi dokumen yang dilakukan melalui telaah pustaka dimana dokumen-dokumen yang dianggap menunjang dan relevan dengan permasalahan yang akan diteliti.

\section{PEMBAHASAN}

Suatu layanan tentunya diharapkan dapat memberikan kemudahan bagi penggunanya dalam hal ini adalah masyarakat. Namun dalam realitasnya jika berbicara pelayanan publik yang diselenggarakan pemerintah biasanya mengalami berbagai hambatan sampai dengan penyimpangan-penyimpangan dalam proses layanan seperti pungutan liar atau pungli dalam proses layanan. Sehingga wajar saja jika saat ini layanan yang diberikan oleh sektor Pemerintah kalah jauh oleh layanan yang diberikan oleh sektor Swasta. Sehingga dari hal tersebut diatas, Pemerintah berupaya melakukan berbagai terobosan-terobosan guna memecahkan permasalah tersebut diatas melalui Inovasi layanan. Salah satunya adalah inovasi yang dilakukan oleh BAPENDA melalui layanan aplikasi SAMBARA secara online.

Tentunya hal tersebut diharapkan dapat memberikan kebermamfaatn yang besar bagi masyarakat khususnya masyarakat Jawa Barat.

\section{A. Kebermamfaatan Inovasi Layanan Aplikasi SAMBARA}

Untuk melihat kebermamfaatan dari Inovasi Layanan Aplikasi Sambara ini sebetulnya dapat dilihat dari tiga fungsi yang dimiliki aplikasi SAMBARA. Kebermamfaatan aplikasi layanan ini tentunya pula dilihat dari seberapa fungsionalnya aplikasi layanan tersebut bagi masyarakat Jawa Barat. Untuk fungsi yang pertama, yaitu Mengecek pajak kendaraan bermotor dan bayar pajak. Masyarakat Jawa barat dapat melakukan pengecekan pajak kendaraan secara online menggunakan aplikasi SAMBARA. Berdasarkan persepsi beberapa masyarakat Jawa Barat, bahwa penggunaan aplikasi layanan SAMABARA sangat mudah dan memudahkan masyarakat. karena masyarakat dapat mengecek dimana saja melalui smart phone nya terkait total nominal pajak kendaraan yang harus dibayarkan, tanpa musti datang ke Kantor SAMSAT. Dan bisa membayar juga melalui aplikasi layanan SAMBARA ini dengan pilihan melalui SMS atau E-Banking. Meskipun pembayaran bisa secara online, namun untuk pengesahan berkas dokumen pajaknya tetap harus di kantor SAMSAT, SAMSAT Keliling, atau Kantor Kepolisian yang ditunjuk, maupun Bank-Bank yang ditunjuk oleh SAMSAT. Dalam fungsi yang pertama ini masyarakat memberikan respon yang begitu 
positif. Fungsi yang kedua, Mengetahui jadwal SAMSAT Keliling. Dilihat dari fungsi ini pun masyarakat memberikan respon yang positif, dengan layanan aplikasi SAMBARA ini, masyarakat dapat mengetahui kapan waktunya mereka dapat membayar pajak di SAMSAT Keliling bagi masyarakat yang tidak mau membayar secara online. Fungsi yang Ketiga, Mengetahui lokasi pelayanan samsat keliling. Selain fungsi yang kedua untuk engathui jadwal kapan samsat keliling, dengan aplikasi layanan ini, masyarakat dapat mengetahui tempat atau lokasi dimana dia dapat membayar pajak pada samsat keliling.

Dari tiga fungsi tersebut jika dilihat kebermamfataan berdasarkan persepsi masyrakatt tentunya inovasi layanan aplikasi SAMBARA ini sangat banyak membantu masyarakat untuk membayar pajak kendaraan bermotornya kapan saja dan dimana saja. Tentunya pula kebermamfaatan ini pun memberikan dampak yang positif bagi pemerintah provinsi sendiri bahwa dengan semakin mudah masyarakat mengecek dan membayar pajak kendaraan, tentunya akan semakin meningkatkan kesadaran masyarakat Jawa Barat membayar pajak kendaraan bermotor, yang pada akhirnya meningkatkan pendapatan pemerintah daerah provinsi.

\section{B. Faktor Yang Menyebabkan BAPENDA Dapat Melakukan Inovasi Layanan Aplikasi SAMBARA}

Berbicara inovasi layanan termasuk inovasi layanan aplikasi SAMBARA, ini memang tidak lepas beberapa faktor pendukung, diantaranya adalah political will dari para pejabat dalam hal ini pihak penyelenggara atau eksekutif, legislatif, kemudian pula tidak lepas dari faktor pendukung lainnya yaitu kontribusi dari pihak swasta baik itu perbankan ataupun perusahaan-perusahaan atau toko online semacam bukalapak, indomaret yang mengakomodir pembayaran pajak tahunan kendaraan bermotor, yang memudahkan masyarakat dalam mendapatkan layanan ini.

\section{KESIMPULAN}

Dari penjelasan singkat diatas dapat disimpulkan bahwa layanan aplikasi SAMBARA ini sangatlah membantu masyarakat Jawa Barat dalam mengecek maupun membayar pajak kendaraan bermotor, artinya inovasi layanan aplikasi SAMBARA ini memiliki kebermamfaatan yang begitu besar bagi masyarakat Jawa Barat.Tentunya hal ini tidak lepas dari dukungan faktor leadership serta peran sektor swasta pula yang berkontribusi dalam operasional dari layanan aplikasi SAMBARA ini. Meskipun demikian, layanan aplikasi SAMBARA ini memang tidak lepas dari beberapa kekurangan, sehingga kekurangankekurangan tersebut dapat diperbaiki. Sehingga kedepannya berfungsi dengan baik. 


\section{DAFTAR PUSTAKA}

BAPENDA, J. B. (2019, Juni 20). https://bapenda.jabarprov.go.id/2018/08/14/cek-pajakkendaraan-melalui-aplikasi-sambara. Retrieved from https://bapenda.jabarprov.go.id

PerMenPan No 30 Tahun 2014 Tentang Pedoman Inovasi Pelayanan Publik. (n.d.).

Ramdani, A. (2018). Penerapan Inovasi Pelayanan Publik Samsat Keliling Di Kota Tasikmalaya. Sawala, 23-30.

Sugiyono. (2006). Metode Penelitian Administrasi. Bandung: Alfabeta.

Suwarno, Y. (2014). Inovasi Di Sektor Publik, 